\title{
PENGEMBANGAN PEMBELAJARAN EKONOMI BERWAWASAN KEINDONESIAAN DI MAN 3 KOTA MALANG
}

\author{
Isnan Nisa Nasution \\ Universitas Muslim Nusantara Al Washliyah \\ isnan.nisa.nasution@gmail.com
}

\begin{abstract}
Abstrak
Tujuan dari penelitian dan pemgembangan ini yaitu untuk mengembangkan pembelajaran ekonomi berwawasan keindonesiaan yang di kemas kedalam buku panduan guru dan buku panduan siswa. Buku panduan ini diperuntukkan bagi siswa kelas $X$ semester 1. Penelitian ini menggunakan pendekatan Design Based Research(DBR).Teknik analisis data yang digunakan adalah kuantitatif dengan teknik statistika deskriptif dan kualitatif. Berdasarkan hasil penelitian pengembangan menunjukkan hasil tanggapan siswapada saat uji coba di MAN 3 kota Malang sebesar 89,2\%. Hal ini berarti bahwa Pembelajaran Ekonomi Berwawasan Keindonesiaan dapat memahamkan peserta didik tentang konsep ekonomi yang sesuai dengan idiologi bangsa Indonesia terutama untuk menanamkan nilai-nilai Pancasiladan UUD 1945 Pasal 33 yaitu nilai kebersamaan dan kekeluargaan yangdiantaranya tercermin pada nilaitoleransi, jujur, tanggungjawab, gotong royong dan demokrasi.
\end{abstract}

Kata kunci: pembelajaran ekonomi berwawasan keindonesiaan, pembelajaran kooperatif

\begin{abstract}
Abtract
The purpose of this research and development is to develop a keindonesiaan-minded economic learning that is packed into teacher manuals and student manuals. This guidebook is intended for students of class $X$ semester 1 . This research uses approach of Design Based Research (DBR) .The data analysis technique used is quantitative with descriptive and qualitative statistical techniques. Based on the results of research development shows the results of responses siswapada when testing in MAN 3 Malang city of $89.2 \%$. This means that the Economics Learning Keindonesiaan can understand the learners about economic concepts in accordance with the ideology of the Indonesian nation, especially to instill the values of Pancasiladan and the 1945 Constitution Article 33 is the value of togetherness and kinship, which is reflected in nilaitoleransi, honest, responsibility, mutual cooperation and democracy .
\end{abstract}

Keywords: economic learning with keindonesiaan insight, cooperative learning

\section{PENDAHULUAN}

Berdasarkan identifikasi masalah yang dilakukan peneliti di MAN 3 kota Malang, mulai dari mengkaji literatur serta analisis kebutuhan guru dan siswa antaralain;penerapan kompetensi inti dalam pembelajaran dikelas masih kurang sesuai dengan RPP yang disusun oleh guru, dimana guru kesulitan dalam mengintegrasikan nilai-nilai yang diharapkan dalam pencapaian Kompetensi Inti kedalam setiap materi. Sehingga penerapan nilai masih sangat memerlukan banyak referensi untuk memudahkan guru dalam menentukan nilai apa yang sesuai untuk diterapkan dalam masing-masing topik pembelajaran. 
Selain itu belum adanya standar baku dalam pengukuran perubahan nilai pada diri siswa sehingga ukuran nilai yang dicapai oleh siswa masih sulit untuk ditetapkan oleh guru. Guru menyatakan pula, banyaknya tindak kejahatan maupun kenakalan remaja menjadikan guru merasa penting untuk menanamkan nilai-nilai moral dalam diri siswa. Dalam wawancara bersama siswa, didapatkan informasi bahwa pembelajaran masih bersifat teoritis dan kurang mengaplikasikan penerapan pembelajaran kelompok selama pembelajaran ekonomi di kelas, maka dibutuhkan pengembangan pembelajaran kooperatif yang menerapkan pembelajaran kelompok agar siswa berinteraksi dengan teman yang lain serta dapat menstimulus siswa untuk menerapkan nilai dalam pembelajaran.

Dari hasil identifikasi masalah tersebut, kemudian peneliti melakukan pengembangan pembelajaran yang dapat membantu guru dalam menerapkan nilai-nilai dalam pembelajaran ekonomi, dimana nilai yang ditawarkan adalah nilai-nilai luhur Bangsa Indonesia yang terkandung dalam Pancasila dan UUD 1945 khususnya pada pasal 33. Dengan pembelajaran tersebut diharapkankedepannya pembelajaran nilai ideologi keindonesiaan ini dapat membantu untuk mencetak generasi penerus bangsa yang berjiwa Pancasila.

Pendidikan berwawasan
keindonesiaan merupakan upaya
terencana pendidik dalam
mengembangkan pendidikan yang
bertujuan menjadikan siswa mampu
memahami nilai-nilai yang tertuang
didalam Pancasila dan UUD 1945
Pasal 33 yaitu kebersamaan dan
kekeluargaan, sehingga membentuk

suatu prinsip keindonesiaan. Dengan penanaman prinsip keindonesiaan dalam diri siswa tersebut, maka akan menjadi proses terstruktur dari terbentuknya karakter siswa, tujuan pendidikan karakter tersebut diharapkan dapatmeningkatkan mutu penyelenggaraan dan hasil pendidikan di sekolah melalui pembentukan karakter peserta didik secara utuh, terpadu, dan seimbang, sesuai standar kompetensi lulusan. Adapun nilai-nilai yang perlu dihayati dan diamalkan oleh guru saat mengajarkan matapelajaran di sekolah adalah: nilai toleransi, jujur, tanggungjawab, gotong royong dan demokrasi. Ki Hadjar Dewantara telah jauh berpikir dalam masalah pendidikan karakter. Mengasah kecerdasan budi sungguh baik, karena dapat membangun budipekerti yang baik dan kokoh, hingga dapat mewujudkan kepribadian (persoonlijkhheid) dan karakter (jiwa yang berasas hukum kebatinan). Jika itu terjadi orang akan senantiasa dapat mengalahkan nafsu dan tabiat-tabiatnya yang asli (bengis, murka, pemarah, kikir, keras, dan lain-lain) (Majelis Luhur Persatuan Tamansiswa, 1977: 24).

Melalui pendidikan ekonomi berwawasan keindonesiaan, diharapkan nilai-nilai luhur Pancasila dan UUD 1945 tersebut dapat tersosialisasi bahkan terinternalisasi dalam diri pribadi generasi muda, yang dalam diri mereka akan tumbuh sikap demokratis serta analitis kritis dalam menghadapi segala permasalahan kehidupan, dan dalam mengaktualisasikan nilai-nilai Pancasila dan UUD 1945. Berdasarkan latar belakang dan beberapa penelitian terdahulu tentang pentingnya mata pelajaran ekonomi yang sekaligus mampu 
menginternalisasikan nilai-nilai ideologi bangsa pada diri siswa, maka peneliti tertarik untuk melakukan penelitian pengembangan berikutnya untuk menambah khasanah penelitian-penelitian sebelumnya yang memang hanya mengaitkan beberapa materi saja, sehingga dengan peneliti melakukan pengembangan pembelajaran dengan materi yang berbeda, peneliti berharap penelitian dapat menjadi pelengkap atas materi-materi sebelumnya yang telah ada. Dan dengan begitu maka akan semakin lengkap pula pengembangan pembelajaran ekonomi yang berlandaskan ideologi bangsa Indonesia yaitu Pancasila dan UUD 1945. Oleh karena itu peneliti mengembangkan penelitian ini dengan judul "Pengembangan Pembelajaran Ekonomi Berwawasan Keindonesiaan di MAN 3 Kota Malang”.

\section{METODE}

\section{Peneliti}

dalam

mengembangkan

model

pembelajaran ekonomi berkarakter Pancasila menggunakan pendekatan Design Based Research (DBR) yang memiliki ciri khusus yaitu sebuah model penelitian pengembangan produk berdasarkan kebutuhan dan yang dibutuhkan serta melibatkan dan berkolaborasi dengan pengguna hasil pengembangan (praktisi).Secara umum penerapan penelitian berbasis desain menggunakan metode yang sistematis namun fleksibel yang bertujuan untuk meningkatkan praktik-praktik pendidikan melalui analisis iterative, desain, pengembangan dan implementasi, berdasarkan kolaborasi antara peneliti dan praktisi secara nyata tanpa adanya rekayasa. Selanjutnya untuk langkah pengembangan dalam penyusunan draft sintaks dan skenario pembelajaran dan uji kelayakan prototipe juga melibatkan tim kolaborasi. Alur yang menggambarkan prosedur penelitian dan pengembangan ini dapat dijabarkan sebagai berikut: (1) Fase Pertama: Mengidentifikasi masalah; (2) Fase 2. Merumuskan Produk Pengembangan; (3) Fese 3.Desain dan Pengembangan Produk; (4) Fase 4. Uji Coba Produk (5) Fase 5. Evaluasi Hasil Uji Coba Produk (6) Fase 6. Mengkomunikasikan Hasil.

Uji Coba Produkyang dilakukan meliputi: 1) Desain Uji Coba; (a) Uji coba ahli materi dan ahli bidang kependidikan, (b) Uji coba praktisi, (c) Uji coba lapangan; 2) Subjek Coba terdiri dari Ahli materi (Bapak Dr. Mit Witjaksono, MS.Ed dan Bapak Dr. Hari wahyono, M.Pd), Ahli Desain (Bapak Prof. Dr. Punaji Setyosari, M.Pd., M.Ed.), Praktisi (Guru bidang studi ekonomi) dan Siswa kelas $\mathrm{X}$ IPS-2 MAN 3 Kota Malang.Instrumen pengumpulan data dalam penelitian dan pengembangan ini antara lain: (a) survei dengan angket untuk tiap individu subjek uji coba, (b) wawancara dalam bentuk diskusi bersama atau berkolaborasi dengan praktisi dan uji coba lapangan, (c) dokumentasi proses pembelajaran ekonomi yang diterjadikan di kelas oleh Guru Ekonomi di MAN 3 Kota Malang yang dilakukan peneliti pada saat mengujicobakan produk pengembangan, kuisioner yang diberikan kepada subjek uji coba pada tahap evaluasi untuk mengetahui kelayakan dan keberterimaan produk yang telah dikembangkan. 


\section{HASIL DAN PEMBAHASAN}

Pelacakan informasi dasar mengenai proses bagaimana pembelajaran yang selama ini terjadi dikelas dilakukan melalui kegiatan survei dan eksplorasi. Kegiatan pertama adalah melakukan kontak awal dengan para praktisi sebagai informan awal. Kontak awal oleh peneliti dilakukan di MAN 3 Kota Malang. Kontak awal dilakukan sebagai pendekatan awal yang dilanjutkan dengan kegiatan pertemuan dengan para praktisi. Pertemuan dengan praktisi dilakukan dengan metode wawancara. Wawancara dilakukan dengan teknik wawancara tidak terstruktur dengan guru ekonomi MAN 3 Kota Malang. Hasil respon para praktisi tersebut akan digunakan sebagai dasar survei lapangan dan eksplorasi. Sumber penyedia informasi kedua adalah siswa MAN 3 Kota Malang. Tahap kedua pertemuan dengan siswa MAN 3 Kota Malang diruang kelas X IPS-2, peneliti menjelaskan tujuan penelitian, membagi angket kebutuhan yang harus diisi siswa. Pengisian angket bertujuan untuk mengetahui kebutuhan siswa didalam proses pembelajaran ekonomi. Eksplorsi lanjut dilakukan setelah komunikasi awal kepada guru dalam hal ini sebagi praktisi dan siswa pada tahap eksplorasi awal. Informasi yang didapat pada eksplorasi lanjut adalah mencakup kondisi aktivitas pembelajaran yang terangkum didalam identifikasi masalah dalam proses pembelajaran secara rinci.

Identifikasi Masalah dan Asesmen

Kebutuhan Terhadap

Pengembangan Pembelajaran 1. 1.

Ekonomi

Berwawasan

Keindonesiaan \begin{tabular}{cc}
\multicolumn{2}{c}{ Berdasarkan identifikasi } \\
masalah yang telah dipaparkan
\end{tabular}

dalam bab sebelumnya, maka beberapa hal yang menjadi langkah awal dalam memulai penelitian ini yaitu diawali pada tanggal 19 Maret 2015 dengan memberikan surat ijin observasi kepada bagian administrasi MAN 3 Kota Malang. Pada tanggal 30 Maret 2015 bertemu dengan Bapak Drs. Agus Anang Fauzian, M.Si selaku guru bidang studi ekonomi yang direkomendasi oleh pihak sekolah untuk menjadi guru pembimbing peneliti. Peneliti menjelaskan rancangan penelitian yang akan dilakukan pada Juni 2015. Peneliti melakukan survei dan kemudian mengadakan wawancara tidak terstruktur dengan Bapak Anang selaku guru pembimbing matapelajaran ekonomi di MAN 3 Kota Malang kelas X IPS 2 tentang proses pembelajaran ekonomi yang selama ini teijadi di kelas, lalu pada tanggal April 2015 peneliti menyebarkan angket kebutuhan guru dan siswa kelas X IPS 2 MAN 3 Kota Malang tentang bagaimana seharusnya pembelajaran ekonomi yang harusnya terjadi di kelas.

Pada bulan April juga, peneliti melakukan survei di MAN 3 Kota Malang untuk melakukan pengamatan bagaimana pembelajaran ekonomi yang teijadi di kelas selama ini. Sebelum melakukan pengamatan, peneliti menganalisis RPP (Rencana Pelaksanaan Pembelajaran) Ekonomi yang dimiliki oleh guru matapelajaran ekonomi kelas $\mathrm{X}$ di MAN 3 kota Malang. Selanjutnya peneliti melakukan survei di MAN 3 Kota Malang untuk menganalisis dan mengamati pembelajaran ekonomi yang terjadi di kelas yang kemudian 
dikroscekkan dengan RPP ekonomi yang telah dibuat oleh guru.

Perumusan Produk Pengembangan Dengan Berkolaborasi Bersama Praktisi, Tim Ahli dan Peserta Didik.

\begin{tabular}{lr}
\multicolumn{1}{c}{ Dalam } & merumuskan \\
pembelajaran & ekonomi \\
keindonesiaan & dilakukan \\
kolaborasi
\end{tabular} antara peneliti, tim ahli, praktisi dan peserta didik. Hasil kolaborasi tersebut kemudian diidentifikasi guna pengembangan pembelajaran ekonomi berwawasan keindonesiaan yang sesuai dengan standar isi dan permendiknas serta kebutuhan peserta didik dalam menjadikan pembelajaran ekonomi yang berwawasan keindonesiaan . Setelah peneliti menganalisis angket kebutuhan guru dan angket kebutuhan siswa di dalam pembelajaran ekonomi serta hasil observasi berupa pengamatan kegiatan proses pembelajaran ekonomi, kemudian peneliti mendiskusikan hasil analisis angket kebutuhan guru dan angket kebutuhan siswa di dalam pembelajaran ekonomi dengan tim ahli. Berdasarkan hasil diskusi antara peneliti dengan tim ahli kemudian peneliti merumuskan desain skenario pembelajaran ekonomi dengan mengembangkan buku panduan pembelajaran ekonomi berwawasan keindonesiaan.

\section{Penyusunan Desain dan \\ Pengembangan Pembelajaran Ekonomi Berwawasan}

\section{Keindonesiaan}

Penyusunan desain dan pengembangan pembelajaran ekonomi berwawasan keindonesiaan ini terdiri dari 6 (enam) tahap, yaitu: (1) penyusunan prototype skenario pembelajaran yang didasarkan pada desain konseptual yang berupa pembelajaran ekonomi berwawasan keindonesiaan, (2) validasi oleh tim ahli ahli (Dr. Hari Wahyono, M.Pd. dan Dr. Punaji Setyosari, M.Pd, M. Ed.), (3) revisi I, (4) hasil revisi didiskusikan dengan praktisi (guru matapelajaran ekonomi), (5) revisi II, (6) draf prototype siap untuk diujicobakan di lapangan.

Tahap berikutnya prototipe rencana pelaksanaan pembelajaran (RPP) ekonomi yang akan digunakan di kelas divalidasi oleh praktisi (guru ekonomi MAN 3 Kota Malang) yaitu Bapak Drs. Agus Anang Fauzian, M.Pd. Peneliti menggunakan instrumen penelitian berupa angket dalam memvalidasi prototype RPP yang berisi tentang 20 (dua puluh) poin penilaian dengan 4 (empat) kriteria penilaian yaitu Sangat Baik, Baik, Kurang Baik dan Sangat Kurang.Hasil perhitungan validasi RPP yang dikembangkan peneliti diperoleh skor validasi sebesar $\mathbf{9 1 , 2 5 \%}$ dimana dengan skala 4 atas penilaian validasi ini maka pengembangan RPP berada pada kriteria kevalidan kedua yaitu diantara 75,01\% - 100,00\% sehingga tingkat kevalidan RPP، Sangat Valid (dapat digunakan tanpa revisi)." Namun dikarenakan adanya saran yang diberikan praktisi terkait RPP yang dikembangkan, maka peneliti tetap melakukan revisi terkait yang masukan tersebut.

Setelah peneliti merevisi skenario pembelajaran ekonomi berdasarkan hasil validitas dari praktisi dan akademisi kemudian peneliti mendiskusikan skenario pembelajaran ekonomi yang telah direvisi tersebut dengan tim ahli yaitu yang pertama kepada Bapak Dr. Mit Witjaksono, MS.Ed., dan mendapat masukan agar RPP yang dimasukkan memuat nilai-nilai 
ideologi bangsa Indonesia yaitu Pancasila dan UUD 1945 Pasal 33 Ayat 1. Selanjutnya, peneliti berdiskusi dengan tim ahli yang kedua yaitu Bapak Dr. Hari Wahyono, M.Pd., dan mendapat masukan agar skenario yang dikembangkan tidak terbatas dengan kurikulum tertentu, sehingga pengembangan pembelajaran dapat dipakai/applicable pada kurikulum apapun yang sedang berlaku disekolah yang ingin menggunakannya.

Selain itu, peneliti juga melakukan validasi terhadap desain buku panduan yang dikembangkan. Validasi desain dilakukan oleh Bapak Prof. Dr. Punaji Setyosari, M.Pd, M.Ed dengan menggunakan instrumen penelitian berupa angket validasi desain buku panduan guru dan siswa yang berisi tentang 34 (tiga puluh empat) poin Dari pengolahan data validasi ahli desain diperoleh skor validasi sebesar $\mathbf{6 4 , 7 \%}$ dimana dengan skala 4 atas penilaian validasi ini maka buku panduan guru dan siswa berada pada kriteria kevalidan kedua yaitu diantara 50,01\% - 75,00\% sehingga

tingkat kevalidan desain buku panduan guru dan siswa "Cukup Valid (dapat digunakan dengan revisi kecil)."

\section{Uji Coba Prototipe Skenario Pembelajaran Ekonomi}

Uji coba prototipe buku panduan pembelajaran ekonomi berwawasan keindonesiaan dilaksanakan sebanyak dua kali di MAN 3 Kota Malang. Pada pertemuan pertama peneliti melakukan uji coba perorangan, dimana tujuan uji coba ini adalah agar mendapatkan kritik dan saran dari guru maupun siswa tentang buku panduan guru dan siswa tersebut.
Tujuan penelitian yaitu dapat menjadikan pembelajaran ekonomi yang berwawasan keindonesiaan sehingga terjadi pembelajaran ekonomi yang tidak hanya mengajarkan teori-teori ekonomi tetapi juga menanamkan nilai-nilai Pancasila dan UUD 1945 Pasal 33 yaitu kebersamaan dan kekeluargaan yang didalam keduanya terkandung nilai solidaritas, setia kawan, dan gotong royong.

Peneliti berkolaborasi

dengan guru ekonomi di MAN 3 Kota Malang menentukan kelas yang akan dijadikan subjek coba serta menentukan jadwal pelaksanaan uji coba. Setelah penentuan subjek coba kemudian guru ekonomi mengajak peneliti untuk melakukan observasi subjek coba serta memberikan kesempatan kepada peneliti untuk mengamati kegiatan pembelajaran, yang dimaksudkan agar peneliti dapat melakukan pengenalan diri serta mengetahui karakteristik peserta didik yang akan dijadikan subjek coba dan menjelaskan bahwa untuk pertemuan yang akan datang pada materi kebutuhan akan menerapkan model pembelajaran yang berbeda dengan biasanya. Peneliti menjelaskan sintaks pembelajaran yang akan diterapkan pada pertemuan yang akan datang (pada pelaksanaan uji coba). Setelah melakukan persiapan, peneliti melakukan uji coba prototipe di MAN 3 Kota Malang dilaksanakan pada hari senin tanggal 8 Juni 2015. Pelaksanaan uji coba perorangan berlangsung lancar dengan peneliti sendiri yang menerapkan pembelajaran ekonomi dengan model pembelajaran ekonomi berwawasan keindonesiaan.

Dari penilaian angket pada uji coba perorangan tersebut, maka 
diperoleh nilai $\mathbf{7 6 , 3} \%$ dimana penilaian tersebut berada pada skala diantara $60 \%-79 \%$ dengan kualifikasi "Cukup Menarik" dengan keterangan "Dapat digunakan dengan revisi kecil." Dengan demikian maka produk buku panduan tersbut akan direvisi terlebih dahulu untuk kemudian dilanjutkan dengan uji kelompok kecil pada pertemuan berikutnya. Dari penilaian angket pada uji coba kelompok kecil tersebut, maka diperoleh rata-rata nilai $\mathbf{8 0 , 3} \%$ dimana penilaian tersebut berada pada skala diantara 80\%-100\% dengan kualifikasi "Sangat Menarik" dengan keterangan "Dapat digunakan tanpa revisi". Namun dikarenakan adanya saran yang diberikan siswa terkait pengembangan buku panduan siswa yang dikembangkan, maka peneliti tetap melakukan revisi terkait yang masukan tersebut. Dengan demikian maka produk buku panduan tersbut akan direvisi terlebih dahulu untuk kemudian dilanjutkan dengan uji lapangan pada pertemuan ketiga.

\section{Evaluasi Kelayakan Prototipe Pengembangan Pembelajaran Ekonomi Berwawasan \\ Keindonesiaan.}

Untuk mengetahui layak tidaknya prototipe maka peneliti meminta tanggapan dari peserta didik tentang pembelajaran ekonomi berwawasan keindonesiaan yang telah diterapkan dalam proses belajar mengajar dalam membahas materi "Permasalahan ekonomi dan cara mengatasinya." Sebelum memulai pembelajaran pada Penelitian Lapangan, peneliti memberikan pretest untuk menguji pemahaman siswa terkait materi "Permasalahan ekonomi dan cara mengatasinya." Pencapaian siswa pada pre-test yang dilakukan dikelas X IPS-2 MAN 3 Kota Malang yaitu 66,9\% dan pada post-test diperoleh kenaikan yang signifikan 81, 3\%.Dari kenaikan pencapaian siswa tersebut, peneliti berkesimpulan bahwa penyampaian materi dengan pendekatan pengembangan pembelajaran ekonomi berwawasan keindonesiaan ini sangat efektif untuk menarik siswa dalam pembelajaran dan meningkatkan pemahaman mereka pula.

Peneliti menggunakan angket tanggapan pembelajaran ekonomi berwawasan keindonesiaan sebagai instrumen penelitian dalam menggali dan mengetahui tanggapan peserta didik terhadap kelayakan pembelajaran ekonomi berwawasan keindonesiaan. Berdasarkan hasil analisis terhadap tanggapan peserta didik MAN 3 Kota Malang, maka diperoleh hasil kelayakan sebesar 89,2\%. Dengan hasil persentase tersebut dan diperjelas dengan tanggapan peserta didik berupa data kualitatif dari respon atau tanggapan yang diberikan maka dapat dikatakan bahwa pembelajaran ekonomi berwawasan keindonesiaan dapat diimplementasikan dalam pembelajaran ekonomi pada materi "Permasalahan ekonomi dan cara mengatasinya." Berdasarkan hasil tanggapan secara kualitatif menyatakan bahwa pembelajaran ekonomi berwawasan keindonesiaan dapat memahamkan peserta didik tentang konsep ekonomi yang sesuai dengan idiologi Bangsa Indonesia terutama dapat menanamkan nilainilai Pancasila diantaranya; kebersamaan dan kekeluargaan yang termplementasi dalam sikap toleransi, jujur, tanggungjawab, gotong royong dan demokrasi. 


\section{Penyempurnaan Prototipe dan Mengkomunikasikan}

Secara keseluruhan, penelitian dan pengembangan ini telah mencapai tujuan, yaitu menghasilkan produk berupa; 1) skenario pembelajaran ekonomi berwawasan keindonesiaan ,2) buku panduan guru. 3) buku panduan siswa. Penelitian dan pengembangan ini juga telah menghasilkan beberapa temuan empirik hasil penelitian, yaitu sebagai berikut:

a. Pembelajaran ekonomi yang selama ini terjadi di kelas belum memuat tujuan pendidikan ekonomi yang termaktub dalam standar isi pendidikan ekonomi untuk SMA/MA.

b. Pembelajaran ekonomi yang selama ini terjadi di kelas cenderung bersifat teoritis serta mengusung nilai-nilai liberalisme yang tidak sesuai dengan nilainilai Pancasila sebagai idiologi Bangsa Indonesia sehingga menghasilkan generasi penerus bangsa yang ahli dalam bidang ekonomi liberalisme.

c. Ketidaksesuaian pelaksanaan pembelajaran ekonomi yang terjadi dengan rencana pelaksanaan pembelajaran sehingga pada saat proses pembelajaran ekonomi pendidik seringkali keluar dari konteks materi yang sedang dibahas yang menyebabkan peserta didik mengalami kebingungan dalam memahami materi yang sedang dibahas.

d. Pembelajaran ekonomi tidak menggunakan contoh yang konkrit sehingga peserta didik kesulitan untuk memahami materi. Oleh karena itu, ketika peneliti menerapkan pembelajaran ekonomi dengan pembelajaran ekonomi berwawasan keindonesiaan mendapat respon yang baik karena mengangkat permasalahan ekonomi yang seringkali dihadapi oleh peserta didik.

e. Menyadarkan peserta didik bahwa pembelajaran ekonomi sangat bermanfaat dalam penyelesaian masalah-masalah ekonomi yang sering dihadapi siswa.

f. Pada sesi presentasi membuat suasana pembelajaran lebih menyenangkan karena bisa membangkitkan minat audien dan penyaji untuk belajar lebih mendalam tentang ekonomi.

\section{Hasil Pembelajaran}

Kajian dalam refleksi pembelajaran melalui pengembangan pembelajaran ekonomi berwawasan keindonesiaan adalah untuk melihat (1) kemampuan siswa dalam menganalisis permasalahan ekonomi (2) analisis siswa dalam menyelesaikan permasalahan ekonomi dengan sistem perkonomian. Berdasarkan hasil kegiatan pembelajaran yang terdiri dari kegiatan eksplorasi awal, lanjut dan tindakan dapat dilihat perubahan yang terjadi pada siswa baik secara personal ataupun kelompok. Secara personal ataupun kelompok siswa mampu mengalami perubahan wawasan dalam menganalisis solusi atas permasalahan ekonomi, ini dibuktikan pada tahap pre-elimanary survey sebelum kegiatan pembelajaran berlangsung siswa hanya memahami permasalahan ekonomi sebagai sesuatu yang biasa. Namun setelah kegiatan pembelajaran berlangsung siswa memahami permasalahan ekonomi menjadi sangat penting untuk 
kemudian ditemukan solusi yang tepat dalam mengatasinya.

Ditinjau dari segi outcome yang diperoleh dari kegiatan pembelajaran terjadi perubahan wawasan siswa yang teraplikasi melalui kemampuan berfikir kritis-analitis dalam menerapkan pemahaman tersebut kedalam penyelesaian suatu kasus dalam kegiatan. Hasil dari kegiatan adalah (1) Aktifitas ekonomi yang dilakukan siswa dilandasi dengan etik dan moral agama, tidak memaksa atau merugikan orang lain,

(2) Keadilan didalam pembagian tugas kelompok dilakukan atas kesepakatan bersama (3) Dalam melakukan kegiatan diskusi, setiap anggota mendapat kesempatan yang sama dalam menyampaikan gagasan atau pemikirannya (4) setiap permasalahan diselesaikan bersama sampai Terbentuk musyawarah dan mufakat (5) Semua bentuk kegiatan harus dikerjakan secara bersama dan disepakati bersama.

Hasil pembelajaran juga diperkuat oleh kemampuan berpikir kritis siswa yang juga dirasakan muncul ketika menyelesaikan suatu masalah dalam kelompok saat mereka berinteraksi bersamaa dalam menyelesaikan suatu masalah, dimana mereka merasakan keegoisan berpendapat dapat terkikis dengan dibangunya pemikiran dari sudut pandang yang menciptakan kesepahaman dan kesepakatan. Secara sistemik budaya kekeluargaan yang diwujudkan melalui situasi kegiatan pembelajaran setelah pengembangan desain pembelajaran telah mampu memberikan perubahan pada sikap, dan ketrampilan kritisanalitis jika dibandingkan dengan sebelum kegiatan pembelajaran berlangsung, dengan situasi yang diciptakan melalui simulasi, siswa telah mampu membentuk sikap kerjasama antar kelompok yang diwujudkan dengan keterlibatan semua anggota dalam menyelesaikan penugasan kelompok yang diberikan. Budaya kekeluargaan secara sistemik dialami siswa melalui kegiatan musyawarah yang terjadi pada saat kegiatan pembelajaran menerapkan pengidentifikasian terhadap permasalahan ekonomi dan dalam menyelesaikan masalah dengan menganalisis solusi terbaiknya. Dimana secara personal dirasakan bahwa partisipasi siswa dalam mengembangkan kemampuan berpikir kritis-analistis dapat dibangun bersama dalam kelompok. Masing-masing anak merasakan kegiatan tersebut telah membantu mereka dalam mencapai kesepakatan dan kesepahaman dalam kelompok. Budaya kekeluargaan juga dirasakan meningkat pada saat perumusan kegiatan, perumusan partisipasi serta pemeranserta kegiatan, dimana masing-masing anak dapat berpartisipasi dalam kegiatan tersebut berdasarkan potensi yang dimiliki tiap siswa. Dampak dari simulasi kegiatan dirasakan siswa adalah semakin meningkatnya kerjasama kelompok yang menyatukan berbagai sudut pandang pemikiran siswa, inisiatif untuk membangun usaha bersama siswa muncul melalui proses musyawarah dalam menyusun konsep kegiatan, semua siswa melaksanakan kegiatan bersama serta menyepakati hasil kegiatan.

Maka dari hasil penyajian refleksi tersebut dapat dilihat bahwa pengembangan desain pembelajaran telah mampu memberikan perubahan wawasan, pengetahuan serta pengalaman pada diri siswa secara personal maupun kelompok dalam 
memahami makna kebutuhan yang mampu menyelesaikan masalah yang menyangkut hajat hidup orang banyak. Serta memberikan perubahan kemampuan berpikir kritis dalam menelaah pemahaman yang diperoleh melalui interaksi pembelajaran serta dari kegiatan diskusi dalam penerapan penyelesaian suatu kasus bersama.

\section{KESIMPULAN}

Produk pengembangan ini berupa; 1) Skenario pembelajaran ekonomi berwawasan keindonesiaan 2) Buku panduan guru, 3) Buku panduan siswa. Pengembangan pembelajaran ekonomi berwawasan keindonesiaan dilakukan secara sistematis dengan menyesuaikan kebutuhan peserta didik. Berikut hasil kajian terhadap produk pengembangan, antara lain sebagai berikut:

1. Komponen

pengembangan

ekonomi

keindonesiaan

harapan peneliti

penyusun, guru dan si pengguna, serta sesuai dengan tujuan pendidikan ekonomi.

2. Buku panduan guru dan siswa untuk pengembangan pembelajaran ekonomi berwawasan keindonesiaan ini diperuntukkan untuk materi "Permasalahan ekonomi dan cara mengatasinya."

3. Skenario pembelajaran dengan metode pembelajaran kooperatif memudahkan penerapan pembelajaran ekonomi yang berwawasan keindonesiaan

4. Skenario pembelajaran ekonomi berwawasan keindonesiaan ini dapat menanamkan nilai-nilai karakter yang sesuai dengan idiologi Bangsa Indonesia, yaitu nilai kebersamaan dan kekeluargaan yang keduanya terinternalisasi dalam nilai toleransi, jujur, tanggung jawab, gotong royong dan demokrasi.

5. Buku panduan pembelajaran ini dapat memudahkan pendidik dalam mengajarkan nilai-nilai karakter dalam materi "Permasalahan Ekonomi dan Cara Mengatasinya."

\section{DAFTAR PUSTAKA}

Abbas, Anwar. 2010. Bung Hatta Dan Ekonomi Islam.Jakarta: Kompas.

DEPDIKNAS. 2003. SistemPendidikan Nasional ( $U U$ RI No 20 Tahun 2003 ) beserta peraturan pelaksanaanya. Jakarta: Departemen Pendidikan Nasional.

Ki Hadjar Dewantara. 1977. Bagian Pertama: Pendidikan. Yogyakarta: Majelis Luhur Persatuan Taman Siswa.

Mubyarto. 1988. Wawasan Ekonomi Pancasila (Majid, A. \& Swasono, S.E., Eds). Jakarta: UI-Press. 1987. Ekonomi Pancasila: Gagasan dan Kemungkinan. Jakarta: LP3ES.

.......... 2004. Ekonomi Pasar Populis, Edisi I. Yogyakarta: Aditya Media \& PUSTEP UGM

Salam, B. 1996. Filsafat Pancasilaisme. Jakarta : PT Rineka Cipta

Suprijono, Agus. 2009. Cooperative Learning Teori dan Aplikasi PAIKEM. Yogyakarta: Pustaka Pelajar.

Sutirman, M.Pd.2013. Media \& Model-Model Pembelajaran Inovatif. Yogyakarta: Graha Ilmu. 
Swasono, S.E. 2009. Keparipurnaan

Ekonomi Pancasila: Menegakkan

Ekonomi Pancasila. Makalah

untuk kongres Pancasila

Kerjasama Universitas Gadjah Mada dan Mahkamah Konstitusi

UGM, Yogyakarta, 30 Mei-1

Juni.

Wang, F. \& Hannafin, M.J. 2005.

Design Based Research and Technology Enhanced Learning

Environments. Educational

Technology Research \&

Development (ETR\&D), Vol. 53,

No. 4, pp.5-23.

Witjaksono, M. 2010. Peningkatan

Kualitas Proses dan Hasil

Pembimbingan Skripsi

Mahasiswa Melalui Implementasi

Pos-Skripsi. Jurusan Ekonomi

Pembangunan, Fakultas Ekonomi,

Universitas Negeri Malang. 